The University of San Francisco

USF Scholarship: a digital repository @ Gleeson Library |

Geschke Center

Sport Management

College of Arts and Sciences

2014

\title{
Sports on Television: The How and Why Behind What You See
}

Michael M. Goldman

University of San Francisco, mmgoldman@usfca.edu

Follow this and additional works at: http://repository.usfca.edu/sm

Part of the Sports Management Commons, and the Television Commons

\section{Recommended Citation}

Goldman, Michael M. (2014). Sports on Television: The How and Why Behind What You See. Journal of Sport Management, 28(3), pp. 376-377. https://doi.org/10.1123/jsm.2014-0100

This Article is brought to you for free and open access by the College of Arts and Sciences at USF Scholarship: a digital repository @ Gleeson Library | Geschke Center. It has been accepted for inclusion in Sport Management by an authorized administrator of USF Scholarship: a digital repository @

Gleeson Library | Geschke Center. For more information, please contact repository@usfca.edu. 


\section{Sports on Television: The How and Why Behind What You See}

By Dennis Deninger. Published in 2012 by Routledge (236 pages)

Reviewed by Michael M. Goldman, Assistant Professor, University of San Francisco, and Adjunct Faculty at the Gordon Institute of Business Science.

“I am not sure what it is we're doing here, but I certainly hope it turns out well for you people who are watching.” These were the hopeful words that NBC’s Bill Stern opened the telecast of the first televised sports game with on May 17, 1939. That day, approximately 400 operating television sets - each with a screen not much larger than a playing card - broadcast "grainy black and white” (p. 11) images of Princeton’s baseball victory over Columbia University. Bill Stern’s words provided the basis for the question that Dennis Deninger attempted to answer in his first book, Sports on Television: The How and Why Behind What You See, some 73 years later.

It is fitting that the three-time Emmy Award-winning television producer, Dennis Deninger, authored this extensive discussion of the sports television industry. Deninger spent 25 years at ESPN leading production teams for studio programming, live remote events and digital video platforms, including being one of the first four coordinating producers for “SportsCenter.” As a Professor of Practice in Sport Management at Syracuse University, Deninger has worked with students to explore the history and culture of sport in the US, which is a theme he also developed in the opening chapters of Sports on Television. Importantly, Deninger positions sports television as unscripted 
human drama, which differentiates this "competition with a story line” (p. 87) from other entertainment offerings, and which may make live sports television DVR-proof.

Within the first 90 pages of Sports on Television, Deninger provides comprehensive coverage of the history, context and development of television in the US, including the important role played by sports productions. This fast-paced section from Chapters 2 to 5, tells the compelling story of how sports became part of “America's connective tissue” (p. xi). Deninger weaves relevant anecdotes from Don Larsen’s World Series perfect game in 1956, to the Sports Broadcasting Act of 1961, to Super Bowl I that reached over 41\% of US homes in January 1967. Each historical event is usefully linked to an explanation of how sports television practice has developed. One interesting example from 1968 is NBC’s infamous “Heidi Game” (p. 52), in which the network cut away to the scheduled children's film Heidi, after the New York Jets had taken a 3-point lead with 1:15 left on the clock. Fans missed the two late Oakland touchdowns and the impact saw sports television move to a prime time product (think Monday Night Football). For sport marketing students and managers, Deninger's discussion of Ed Sabol's Blair Productions in the early 1960s, and its subsequent evolution into NFL Films, provides an important illustration of the power of promotional messaging. For the NFL, Sabol's epics communicated that NFL football was "filled with fun, thrilling moments, dramatic story lines, hard-working heroes, and was entertaining for women and men” (p. 62).

Deninger concludes his historical review with an in-depth case study of ESPN in Chapter 5. With his first-hand experience in the business, Deninger is able to map the strategic drivers, challenges and implications of the growth of the Entertainment and 
Sports Programming Network. Sport strategy students and managers will find the "keys to victory" (p. 65) section, as well as the analysis of how Bill Rasmussen overcome the four substantial interdependent challenges, of particular interest. Specifically, Deninger explores Rasmussen’s programming challenge (solved through the NCAA deal), financing challenge (Getty Oil profits investment), cable systems challenge (paying the cable providers to carry ESPN), and advertising challenge (Anheuser-Busch exclusivity).

Dennis Deninger changes tack from Chapter 6 to provide more practical and direct guidance to sports television students and managers. Chapters 6, 7 and 8 provide a detailed, and sometimes even quite basic, explanation of programming, producing and commentating of sports on television. These guidance sections will be useful to those wanting to understand how to deliver superior sports productions. Deninger deals in detail with the critical role of storytelling and even highlights the different job roles involved. By drawing on ABC's Keith Jackson's famous one-line job description of a commentator to “amplify, clarify, punctuate and enjoy" (p. 120), Deninger shares valuable practitioner experience for anyone looking to increase his or her game as on-air talent. Sports on Television looks abroad in Chapter 9 to provide a useful discussion of international sports broadcasting, although limited to an US audience perspective. This chapter draws on US broadcaster experiences in Russia, Europe, Africa and Latin America, but perhaps fails to consider practices of non-US sports broadcasters operating in these markets. Given the increased sports rights competition from Asian broadcasters, such as StarTimes, and the dominance of SuperSport in Africa, as well as the mixed response that traditional US-produced sports media has received outside the US, those looking to operate more globally may find Chapter 9 somewhat limited. Interestingly, 
Sports on Television is currently being translated into simple Chinese - further evidence of the on-going globalization of the sports industry.

The US sports television consumer takes center stage in Chapters 10 and 14. Deninger employs Nielsen data to understand who is watching sports television as well as some aspects of how they are consuming this media. The 'Why they are watching' question is more fully dealt with in Chapter 14, where Deninger draws on Octagon's Passion Drivers ${ }^{\mathrm{TM}}$ research. The chapter on advertising and sponsorship is written more from a client brand's perspective than a media network's perspective, resulting in less of a thematic fit with the rest of the book. The final set of chapters explores the political (organizational and industry) and Political (governmental) nature of sports television. Deninger challenges students and managers to take a broader stakeholder perspective in understanding the complexities and interdependencies involved within sports television, and between sports television and the rest of society. This discussion raises important questions of power and influence, which need to be navigated by anyone hoping to survive and thrive within sports television.

Sports on Television includes discussion topics or assignments at the end of each chapter which encourage the reader to reflect on the application and extension of the preceding discussion. Deninger provides a 3-page bibliography at the end of the book, which mostly draws on media reports and sports organizations or individuals. As a possible text for sports media students, the book lacks integration of existing research from Sport Marketing Quarterly, the International Journal of Sports Marketing \& Sponsorship, or the broader Journal of Sport Management. Primary course texts such as Raney and Bryant’s (2006) Handbook of Sport and Media, and Nicholson’s (2006) Sport 
and the Media: Managing the Nexus may provide a useful balance for undergraduate and graduate sport management programs. It is unlikely that Sports on Television will be used as the primary text in a sport media or management course, although it would be an engaging supplemental resource, especially for students less familiar with the historic US sport media context.

In his foreword to the book, ESPN Executive Chairman George Bodenheimer suggests that we haven't yet approached the saturation point for fans' 'unquenchable thirst for sport." Sports on Television provides a comprehensive and engaging platform for thinking about how to meet sports media consumers' thirst in the years ahead. 